\title{
Teaching Quality Management Model for the Training of Innovation Ability and the Multilevel Decomposition Indicators
}

\author{
Xingjiang $\mathrm{Lu}^{1}$, Chen $\mathrm{Yao}^{1} \&$ Jianmin Zheng ${ }^{2}$ \\ ${ }^{1}$ Department of Mathematics, Zhejiang University, Hangzhou, China \\ ${ }^{2}$ School of Computer Engineering, Nanyang Technological University, Singapore \\ Correspondence: Xingjiang Lu, Department of Mathematics, Zhejiang University, Hangzhou, Yugu Road, China. Tel: \\ 86-571-87953764, 86-139-6802-0706. E-mail: xjlu@zju.edu.cn
}

Received: July 11, 2013

doi:10.5430/ijhe.v2n3p115
Accepted: July 30, 2013

Online Published: August 1, 2013

URL: http://dx.doi.org/10.5430/ijhe.v2n3p115

\begin{abstract}
This paper focuses on the training of undergraduate students' innovation ability. On top of the theoretical framework of the Quality Function Deployment (QFD), we propose a teaching quality management model. Based on this model, we establish a multilevel decomposition indicator system, which integrates innovation ability characterized by four primary indicators and their corresponding secondary indicators, curriculum, pedagogy, teaching forms and assessment. The proposed model and indicators provide guidance for university curriculum development, university education management and practice.
\end{abstract}

Keywords: Innovation ability, Teaching quality management model, Multilevel decomposition indicators, Undergraduate education

\section{Introduction}

In order to develop technology and enhance national competitiveness, it is an important task to nurture the innovation ability of young talents with forward-looking. The goal of higher education is to foster scientific literacy and creativity. How to improve the quality of university teaching through scientific teaching methodology and management is an important issue to ensure the first-class personnel training required for innovation talent development.

Systematic curriculum study is essential to empower student to have forward-looking ability of knowledge innovation. In this paper, aiming towards fostering the innovation ability, we propose a teaching quality management model (TQMM) according to the framework of quality function deployment (QFD) theory (American Supplier Institute 1989) and students' innovation ability index system. This model is established based on previous work (Wang and Cao 2007). It involves five steps: requirement identification, information gathering, indicator assessment, methodology selection, and implementation evaluation. After that, we further combine four primary indicators and the corresponding secondary indicators in the innovation ability with curriculum, pedagogy, teaching forms, assessment, and other factors to establish a multi-level decomposition indicator system. In this way, the requirement of the innovation ability training and the subjective indicators of innovation ability evaluation are naturally combined under the classical theory and the common practice. The proposed quality management model and decomposition indicators can be used for university curriculum development and class teaching. It provides effective guidance to the research and practice for the training of innovation ability.

\section{Construction of Teaching Quality Management Model for Innovation Ability Training}

\subsection{The Index System of University Student Innovation Ability}

The cultivation of talents with the ability of original knowledge creation is a gradual process that requires proper training and exposure to appropriate circumstances. It is formed gradually through various activities in practice. Therefore it is very important to provide a systematic university education with high quality.

Ability refers to those psychological characteristics that people must have in order to accomplish an activity successfully. It is always related to certain human activities and the performance. It is also developed in practice based on heredity (Lin Chongde et al. 2003). The aptitude means the possibility for one to complete a task after being properly trained or placed in appropriate circumstances (Brown, 1983). 
In some countries, particularly the United States, Britain, France, Japan and other developed countries, the innovation education and the cultivation of students' innovation ability have been studied extensively. Those countries have the tradition of treating the innovation ability training as one basic teaching target. For example, American college Scholastic Aptitude Test (SAT) is a test that mainly measures students' verbal reasoning ability (SAT-V) and mathematical reasoning ability (SAT-M). It is conducted annually by the Educational Testing Service. Since 1994, the tests have been increasing the emphasis on measuring students' reasoning and critical thinking ability (James et al. 1985; Minke et al. 1996). The Examination Validity Research Center of U.S. College Board has conducted over 2000 validity experiments and analysis on 700 universities. The research result indicates that the scores of SAT and the scores of freshman examination have strong relation with the correlation coefficient of 0.42 (Kenneth et al. 1990). It is also worth pointing out that the first year study at university is critical for training students' innovation ability.

In recent years, with the increasing demand of the innovation talents, research on the theory and practice for student innovation ability-building has made substantial progress (Chen and Wang 2006, Wang and_Cao 2007). The research covers the patterns of students' creativity, the innovation ability training strategy, the assessment, etc. In particular, Wang and Cao studied the current Chinese student innovation features and patterns, based on which they designed a student innovation ability index system (Wang and Cao 2007). Furthermore, they performed both qualitative and quantitative analysis and used the multi-level fuzzy comprehensive evaluation of expert ratings as well to establish a multi-level decomposition model for student innovation ability evaluation. The model has been applied in practice and it provides a first attempt to comprehensively evaluate students' innovation ability using indicators. However, whether the model is scientific and rational has yet to be tested in practice. In particular, the expression of the indicators appears to be subjective and the operability of the model is difficult.

In this paper, we aim to improve Cao and Wang's work by proposing a new teaching quality management model that is less subjective and easy to operate in practice. For this purpose, we look into the student innovation ability indicators and evaluation by combining the needs of the knowledge innovation talent training with the characteristics of course teaching in classroom. We also consult a number of professors or education experts who have had many years' experience in teaching, research and administration. After careful analysis and integration, we propose to adapt the student innovation index system. The adapted index system has four primary indicators: innovation learning ability, innovation knowledge foundation, creative thinking ability, and innovation skills. Corresponding to them, we also design the secondary indicators (see Table 1). Both the primary and secondary indicators form a comprehensive Evaluation Index System, which is suitable for course teaching in classroom.

Table 1. Comprehensive evaluation index system of student innovation ability

\begin{tabular}{ll}
\hline Primary indicators & Secondary indicators \\
\hline Innovation learning ability & Ability of problem identification \\
& Ability of information retrieval \\
& Ability of knowledge updating \\
& Ability of uniqueness exposition \\
Innovation knowledge foundation & Basic knowledge level \\
& Cross-discipline knowledge level \\
Creative thinking ability & Knowledge innovation level \\
& Intuitive thinking \\
& Logical thinking \\
Innovation skills & Imagination \\
& Critical thinking \\
& Methodology innovation \\
& Knowledge application \\
\hline
\end{tabular}

\subsection{QFD-based Teaching Quality Management Model}

In past two decades, quality function deployment, as one of the core tools of customer-driven quality engineering, has been increasingly showing its great theoretical and practical value in the quality management discipline. QFD is 
considered as a powerful tool for enterprises to implement customer satisfaction oriented comprehensive quality strategy in the twenty-first century. The main idea of QFD is to convert the customer needs into a set of appropriate requirements in each stage of enterprises (such as research, product design and development, manufacturing, assembly and sales and after-sales service). In general, QFD can also be understood to consist of two components: comprehensive Function Quality Deployment and narrow Quality Function Deployment. The key is to identify and determine what the customer's real needs are, which help to decide how to realize and meet customer needs (American Supplier Institute 1989; Shigeru Mizuno et al. 1994).

In this paper we use QFD to establish our teaching quality management model for innovation ability, which aims to strengthen the training content for enhancing students' reasoning and critical thinking ability. The content includes three parts: reasoning, comparison and application. Current university curriculums can be roughly divided into four categories: general education courses, foundation courses, specialized foundation courses and specialized courses. Among them, the general education courses and foundation courses are for the 1st and 2nd years, while specialized foundation courses and specialized courses are for the 3rd and 4th years. Each course is offered once a year. To ensure the quality of teaching, the teaching process is monitored and the corresponding teaching management system is adjusted accordingly.

Fig. 1 shows our proposed teaching quality management model. The model is built based on the Quality Function Deployment theory. It takes the above-mentioned evaluation indicators as the core and meanwhile considers the actual teaching practice. The model converts the innovation training requirements into teaching quality properties. The corresponding teaching process is divided into five steps: talent training plan, innovation ability requirements, system modeling, multi-level decomposition of indicators and evaluation feedback. Moreover, the model systematically disposes the relation between innovation ability indicators and teaching characteristics, thereby guaranteeing the overall teaching quality of the students' innovation ability training. The deployment mainly contains teaching quality, teaching methods, teaching resources, and feasibility. As the goal, innovation ability runs through the entire process of education quality management. It has four modules: innovation learning ability, innovation knowledge foundation, creative thinking ability and innovation skills, which correspond to general education courses, foundation courses, specialized foundation courses and specialized courses in the teaching system, respectively.

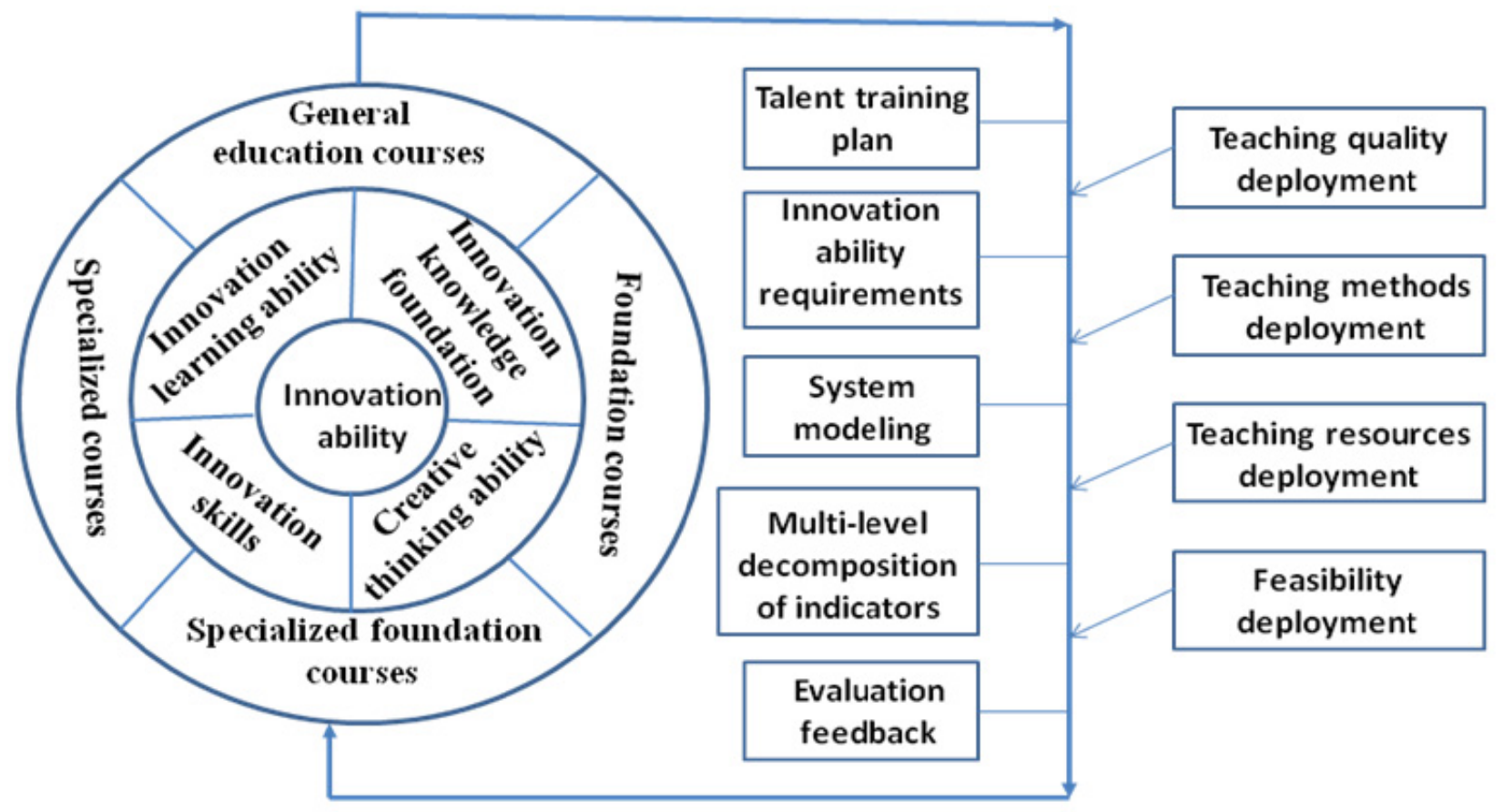

Figure 1 . The teaching quality management model for innovation ability training

\section{Multi-level Decomposition Indicators Based on Teaching Quality Management Model}

Research-oriented innovation talents are those high-level professional people who aim towards innovating knowledge, pursue truth, and have creative, independent and critical thinking. In this paper, we integrate the typical thinking patterns and skills that are required in the innovation ability training into specific courses and increase the training content for students' reasoning and critical thinking. The proposed index system and management model in 
the previous section are refined into a multi-level decomposition index system. In particular, the system is designed to strengthen the training of students' scientific thinking and innovation. It will lay a solid foundation for the forward-looking primitive knowledge innovation talent training.

TRIZ is a theory of inventive problem solving, which was developed based on the objective laws of technical systems evolution rather than psychological foundation. ARIZ is a systematic approach of using TRIZ to solve complex conflict problems. It is a logical structured process that integrates different pieces of TRIZ and incrementally evolves a complex problem to a situation where it is simple to solve. That is, ARIZ consists of a series of clear knowledge-based logic rules, and starting with conflict analysis, it guides people to get an ideal solution for a situation with complete elimination of conflicts in the end (Wei Zihui et al. 2008). It formulates the conflict (contradiction) as a "mini-problem", then guides the problem solver to go towards the desired results, and finds a simple and effective way to solve the problem with minimum cost. The final ideal solution not only meets the requirements of the conflicts, but also maximizes the use of resources.

Fig. 2 depicts the flow chart of our multi-level index composition, which is under the overall framework of courses teaching quality management model for innovation ability training and designed in accordance with the logic processes of ARIZ. We start with an initial description of innovation ability, and based on the deep understanding of innovation ability we narrow down our problem and concentrate on 4 primary indicators and their secondary indicators. Then, we analyze the potential conflicts hiding in the system related to the secondary indicators, identify the conflict areas, find existing teaching resources in the areas, and finally propose a good solution.

In order to obtain an ideal teaching system solution, we analyze all potential conflicts. The key is to identify the areas where the conflicts are, from which we design a specific solution in support of the knowledge base formed by existing teaching theories, methods and content. The conflicts can be separated according to different time, space, or levels. In order to make the solution close to an ideal one, we should make full use of existing resources, reduce the additional resources, and minimize the change of the whole system. If the solution derived based on the secondary indicators is not feasible, it may imply that the initial description of the problem or the narrow-down process is inappropriate. Thus we need to go back to the starting point of the analysis, redefine the secondary indicators, and then find a new solution according to the ARIZ process. Through this analysis, the multi-level decomposition indicators of the teaching quality management model for innovation ability training are substantialized, as given in Tables 2-5.

Table 2. Primary indicator: Innovation learning

\begin{tabular}{lllll}
\hline $\begin{array}{l}\text { Secondary } \\
\text { indicators }\end{array}$ & Pedagogy & Teaching forms & Course contents & Study guidance \\
\hline $\begin{array}{l}\text { Problems } \\
\text { identification }\end{array}$ & $\begin{array}{l}\text { Guide students to } \\
\text { identify problems }\end{array}$ & $\begin{array}{l}\text { Delimit the content of } \\
\text { student self-study, and } \\
\text { ask questions }\end{array}$ & $\begin{array}{l}\text { Knowledge } \\
\text { Background and } \\
\text { causes }\end{array}$ & $\begin{array}{l}\text { Understand the theoretical } \\
\text { background and necessity of } \\
\text { the condition of theorem }\end{array}$ \\
$\begin{array}{l}\text { Information } \\
\text { retrieval }\end{array}$ & $\begin{array}{l}\text { Recommend } \\
\text { reference materials }\end{array}$ & $\begin{array}{l}\text { Search literatures, } \\
\text { collate relevant content } \\
\text { and intellectual points }\end{array}$ & $\begin{array}{l}\text { Main theory and its } \\
\text { proof }\end{array}$ & $\begin{array}{l}\text { Seek a different method of } \\
\text { proof and related corollary }\end{array}$ \\
$\begin{array}{l}\text { Knowledge } \\
\text { updating }\end{array}$ & $\begin{array}{l}\text { Stimulate students' } \\
\text { thinking, introduce } \\
\text { Content Deep }\end{array}$ & $\begin{array}{l}\text { Raise the issue to attract } \\
\text { students and cultivate } \\
\text { interest in learning }\end{array}$ & $\begin{array}{l}\text { Use new theories } \\
\text { and knowledge to } \\
\text { solve problems }\end{array}$ & $\begin{array}{l}\text { Take the initiative to learn new } \\
\text { knowledge through analyzing } \\
\text { the difficulty of the problem }\end{array}$ \\
$\begin{array}{l}\text { Uniqueness } \\
\text { exposition }\end{array}$ & $\begin{array}{l}\text { Encourage students } \\
\text { to express their } \\
\text { views, promote } \\
\text { divergent thinking }\end{array}$ & $\begin{array}{l}\text { Ask questions in class, } \\
\text { discuss in groups and } \\
\text { seek different solutions } \\
\text { to the same problem, } \\
\text { etc. }\end{array}$ & $\begin{array}{l}\text { Theory and its } \\
\text { proof, methods and } \\
\text { techniques of } \\
\text { solving problems }\end{array}$ & $\begin{array}{l}\text { Solve different problems make } \\
\text { use of the characteristics of the } \\
\text { knowledge, consider every } \\
\text { detail }\end{array}$ \\
\hline
\end{tabular}




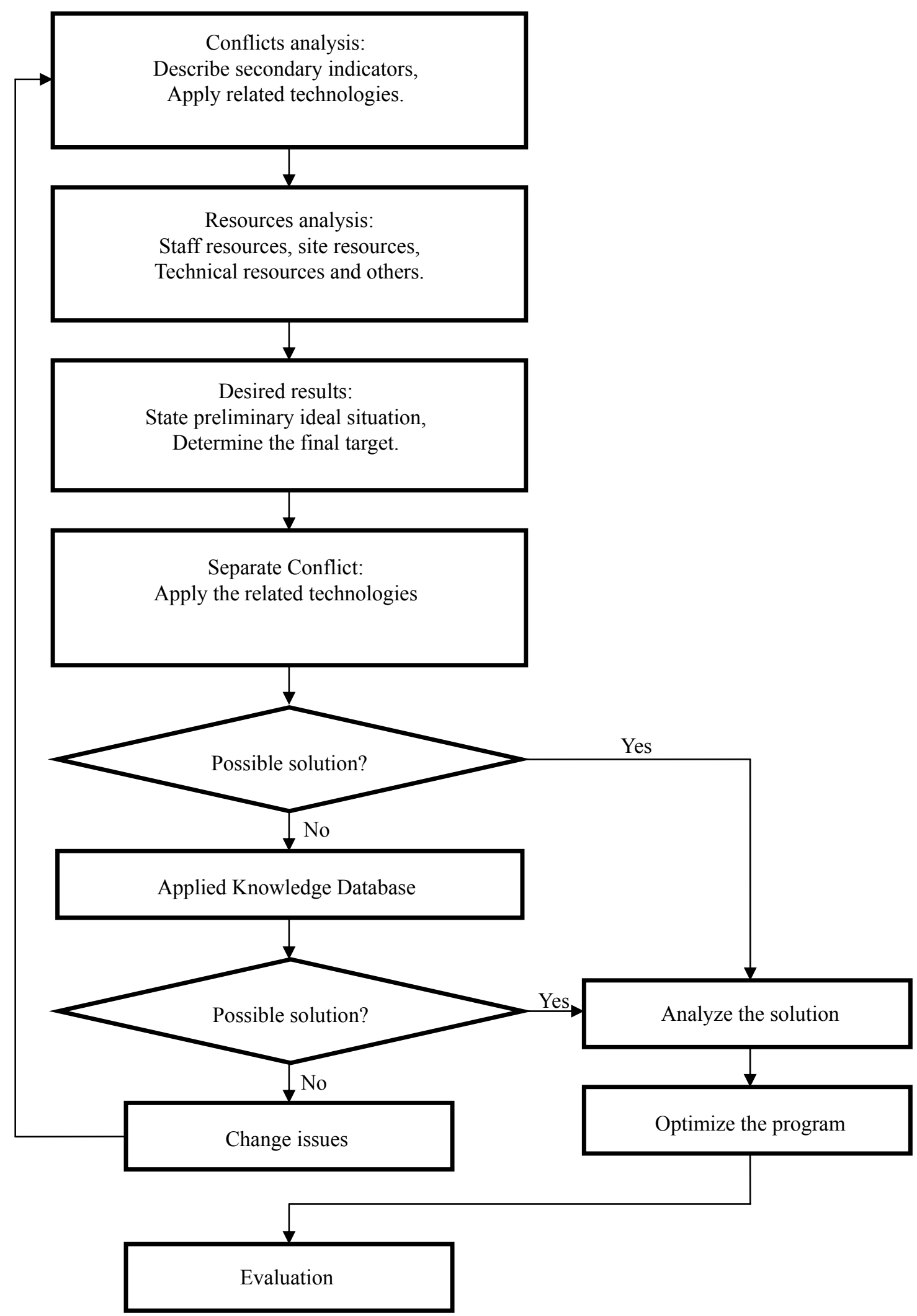

Figure 2. Multi-level index decomposition flow chart of teaching quality management model for innovation ability training 
Table 3. Primary indicator: Innovation knowledge foundation

\begin{tabular}{|c|c|c|c|c|}
\hline $\begin{array}{l}\text { Secondary } \\
\text { indicators }\end{array}$ & Pedagogy & Teaching forms & Course contents & Study guidance \\
\hline $\begin{array}{l}\text { Basic knowledge } \\
\text { level }\end{array}$ & $\begin{array}{l}\text { Introduce inherent } \\
\text { nature of knowledge, } \\
\text { mathematical ideas and } \\
\text { methods }\end{array}$ & $\begin{array}{l}\text { Learn intellectual } \\
\text { content from } \\
\text { different angles } \\
\text { through analysis, } \\
\text { analogy, etc. }\end{array}$ & $\begin{array}{l}\text { Definition, main } \\
\text { theorems and } \\
\text { related } \\
\text { inferences }\end{array}$ & $\begin{array}{l}\text { Comprehend the } \\
\text { definitions, analyze } \\
\text { theory in detail, } \\
\text { understand the nature of } \\
\text { knowledge }\end{array}$ \\
\hline $\begin{array}{l}\text { Cross-discipline } \\
\text { level }\end{array}$ & $\begin{array}{l}\text { Guide students to learn } \\
\text { the knowledge of } \\
\text { various disciplines }\end{array}$ & $\begin{array}{l}\text { Set up various } \\
\text { disciplines general } \\
\text { education courses, } \\
\text { formulate academic } \\
\text { credit requirement }\end{array}$ & $\begin{array}{l}\text { General } \\
\text { education } \\
\text { courses }\end{array}$ & $\begin{array}{l}\text { Learn the basic methods } \\
\text { and classic results of } \\
\text { various disciplines basic } \\
\text { courses, improve the } \\
\text { overall level of } \\
\text { knowledge and } \\
\text { capabilities }\end{array}$ \\
\hline $\begin{array}{l}\text { Knowledge } \\
\text { innovation level }\end{array}$ & $\begin{array}{l}\text { Help students to } \\
\text { master innovation } \\
\text { theoretical knowledge } \\
\text { and problem-solving } \\
\text { methods }\end{array}$ & $\begin{array}{l}\text { Deeply understand } \\
\text { the knowledge, } \\
\text { methods innovation, } \\
\text { different solutions }\end{array}$ & $\begin{array}{l}\text { Innovation } \\
\text { theory, } \\
\text { methods, the } \\
\text { relationship } \\
\text { between } \\
\text { knowledge }\end{array}$ & $\begin{array}{l}\text { Understand the } \\
\text { knowledge from each } \\
\text { side, solve the problem } \\
\text { from different angles and } \\
\text { ways }\end{array}$ \\
\hline
\end{tabular}

Table 4. Primary indicator: Creative thinking

\begin{tabular}{|c|c|c|c|c|}
\hline $\begin{array}{l}\text { Secondary } \\
\text { indicators }\end{array}$ & Pedagogy & Teaching forms & Course contents & Study guidance \\
\hline $\begin{array}{l}\text { Intuitive } \\
\text { thinking }\end{array}$ & $\begin{array}{l}\text { Cultivate students } \\
\text { keen powers of } \\
\text { observation and } \\
\text { intuition judgment } \\
\text { ability of new } \\
\text { knowledge }\end{array}$ & $\begin{array}{l}\text { Use analogy, } \\
\text { recursion, plausible } \\
\text { reasoning and the } \\
\text { combination of the } \\
\text { number and graph }\end{array}$ & $\begin{array}{l}\text { The significance of } \\
\text { the concept, the } \\
\text { symmetry of } \\
\text { graphics and the } \\
\text { duality of some } \\
\text { results }\end{array}$ & $\begin{array}{l}\text { Intuitive understanding of } \\
\text { the nature of knowledge, } \\
\text { especially geometric } \\
\text { meaning and physical } \\
\text { significance, pay attention to } \\
\text { the regularity of forms and } \\
\text { calculations }\end{array}$ \\
\hline $\begin{array}{l}\text { Logical } \\
\text { thinking }\end{array}$ & $\begin{array}{l}\text { Clarify the logic and } \\
\text { introduce the } \\
\text { analytical reasoning } \\
\text { basic method }\end{array}$ & $\begin{array}{l}\text { Introduce the } \\
\text { logical reasoning } \\
\text { ideas and methods } \\
\text { from the theorem } \\
\text { theoretical proof }\end{array}$ & $\begin{array}{l}\text { Theoretical } \\
\text { analysis, the } \\
\text { conclusion of } \\
\text { further promotion }\end{array}$ & $\begin{array}{l}\text { Use logic basics to } \\
\text { understand logical reasoning } \\
\text { principle in the typical way } \\
\text { of thinking }\end{array}$ \\
\hline Imagination & $\begin{array}{l}\text { Stimulate the } \\
\text { imagination, } \\
\text { visualize the concepts } \\
\text { and theories }\end{array}$ & $\begin{array}{l}\text { Interpret knowledge } \\
\text { with graphics, tables, } \\
\text { and symbols }\end{array}$ & $\begin{array}{l}\text { The structure of } \\
\text { system, data } \\
\text { analysis, the nature } \\
\text { of space, the } \\
\text { geometric theory }\end{array}$ & $\begin{array}{l}\text { Find intuitive knowledge } \\
\text { elements, and display } \\
\text { abstractions, reveal the } \\
\text { hidden nature }\end{array}$ \\
\hline $\begin{array}{l}\text { Critical } \\
\text { thinking }\end{array}$ & $\begin{array}{l}\text { Encourage students } \\
\text { to express different } \\
\text { points of view, not } \\
\text { superstitious } \\
\text { authority and } \\
\text { teaching materials }\end{array}$ & $\begin{array}{l}\text { Guide students to } \\
\text { consider the issue in } \\
\text { many aspects, using } \\
\text { different methods to } \\
\text { solve the problems }\end{array}$ & $\begin{array}{l}\text { Theorem } \\
\text { assumption and } \\
\text { results, theoretical } \\
\text { rigor, integrity } \\
\text { analysis }\end{array}$ & $\begin{array}{l}\text { Do not miss any doubt, pay } \\
\text { attention to whether the } \\
\text { statement rigorous, analyze } \\
\text { the necessity of conditions }\end{array}$ \\
\hline
\end{tabular}


Table 5. Primary indicator: Innovation skills

\begin{tabular}{lllll}
\hline Secondary indicators & Pedagogy & Teaching forms & Course contents & Study guidance \\
\hline $\begin{array}{l}\text { Research methods } \\
\text { innovation }\end{array}$ & $\begin{array}{l}\text { Stimulate the } \\
\text { exploring } \\
\text { knowledge desire of } \\
\text { students, carry } \\
\text { forward the } \\
\text { innovation spirit }\end{array}$ & $\begin{array}{l}\text { Explore and design } \\
\text { new methods at the } \\
\text { issues to be } \\
\text { addressed }\end{array}$ & $\begin{array}{l}\text { Novel topics, } \\
\text { cutting-edge } \\
\text { scientific issues }\end{array}$ & $\begin{array}{l}\text { In-depth thinking, } \\
\text { cultivate research } \\
\text { capacity, focus on } \\
\text { creation }\end{array}$ \\
& $\begin{array}{l}\text { Apply theoretical } \\
\text { Knowledge application }\end{array}$ & $\begin{array}{l}\text { Transform practical } \\
\text { problems to the } \\
\text { theory, design } \\
\text { practice, to solve } \\
\text { practical problems }\end{array}$ & $\begin{array}{l}\text { Application of } \\
\text { practical issues and } \\
\text { related fields }\end{array}$ & $\begin{array}{l}\text { Establish the model } \\
\text { of the actual } \\
\text { problem, find the } \\
\text { innovation design } \\
\text { approach }\end{array}$ \\
& & & &
\end{tabular}

\section{Significance of the Teaching Quality Management Model and its Decomposition Indicators}

This paper studies how higher education improves the teaching system in order to train students to think independently and explore freely with high innovation spirit and ability. In particular, the curriculum should be designed to train students to be eager to learn, good at thinking, courageous to explore, and sensitive to the innovation, which thus enable students to become innovation talents with solid theoretical foundation in future. The main contributions of the paper are as follows.

- Construct teaching quality management model through combing the quality management theory and the innovation ability indicator system

This paper identifies the teaching quality management procedures for innovation ability training based on the structural model of quality management theory whose core is the student innovation ability indicators. Through empirical research including discussion, interviews, questionnaires, etc., we have established a teaching quality management model for innovation ability training. This model extends the teaching system quality management theory and is an integration and refinement of comprehensive quality management ideas, innovation indicators and teaching system. The model can serve as a reference for related researches and practical work, and also provide a theoretical guidance for university education reformation and practice.

- Establish multi-level teaching quality management decomposition indicators through combining the innovation indicators with the teaching practice

Based on empirical research, this paper connects student innovation ability indicators to the teaching system and its quality management system to build and validate the quality of teaching management multilevel decomposition indicators. The proposed multi-level decomposition indicators suggest appropriate guidance for pedagogy, targeted pairing for course content and specific learning process, which can help train students to master the basic reasoning and critical thinking skills with prospective original innovation consciousness and improve the teaching quality of courses. This research offers some concrete and feasible indicators for the university curriculum development, broadens the ideas for the classroom teaching quality management, and provides a new starting point and reference for the related research as well.

\section{References}

American Supplier Institute. (1989). Quality function deployment: implementation manual for three-day QFD workshop. Dearborn, ASI. [Online] Available: http://books.google.com.sg/books?id=WiRdtwAACAAJ

Brown, H.E. (1983). Principles of education and psychological testing $\left(3^{\text {rd }}\right.$ ed). Hold, Tinehart, \&Winston, New York. [Online] Available: http://books.google.com.sg/books?id=A3oEAQAAIAAJ

Chen Shuwen, Wang Donghua (2006). Study on technological innovation ability evaluation of IT industry in China. IEEE International Conference on Management of Innovation and Technology. http://dx.doi.org/10.1109/ICMIT.2006.262157.

James V, Mitchell, JR. (1985). The ninth mental measurements yearbook. The Buros Institute of Mental 
Measurements of The University of Nebraska-Lincoln. [Online] Available: http://books.google.com.sg/books?id=dnp-wlyKiIgC

Kenneth D.Hopkins, Julian C.Stanley, B.R.Hopkins. (1990). Educational and psychological measurement and evaluation. Englewood Cliffs, New Jersey. [Online] Available: http://books.google.com.sg/books?id=UIRHAAAAMAAJ

Lin Chongde, Yang Zhiliang, Wang Xiting. (2003). Dictionary of psychology (First volume). Shanghai: Shanghai Education Press, 563.

Minke, Amy. (1996). A review of the recent changes in the scholastic aptitude test reasoning test. ERIC, Report: CBR-96-1,15p. [Online] Available: http://www.eric.ed.gov/PDFS/ED397092.pdf.

Shigeru Mizuno, Yoji Akao. (1994). QFD-The customer driven approach to quality planning and deployment. Asian Production Organization. [Online] Available: http://books.google.com.sg/books?id=9I6YPgAACAAJ

Wang Jiaqi, Cao Yingyi. (2007). Comprehensive evaluation of innovation capability of college students, Journal of Wuhan University of Technology (Information \& Management Engineering), 29(8), 133-137. [Online] Available: http://en.cnki.com.cn/Article_en/CJFDTOTAL-WHQC200708036.htm

Wei Zihui, Yan Huiqiang, Tan Runhua. (2008). The research and application of ARIZ algorithm in TRIZ theory, Journal of Machine Design, 25(4), 57-61. [Online] Available: http://en.cnki.com.cn/Article_en/CJFDTOTAL-JXSJ200804017.htm 